\title{
To Use or Not to Use: Analysis of ICT in the Ideation Process of Graphic Design in the Senior High Schools
}

\author{
Anita Akwaa Toffah ${ }^{1 *} \quad$ Edward Appiah $^{2} \quad$ Albert Boamah $^{3}$ \\ 1.Department of Industrial Arts, Ho Technical University - Ghana. Post Office Box HP 217. Ho Volta Region - \\ Ghana \\ 2.Kwame Nkrumah University of Science and Technology, Department of Communication Design. Private Mail \\ Bag, University Post Office, Kumasi-Ghana \\ 3. University of Education, Winneba, Department of Graphic Design. Post Office Box 25, Winneba-Ghana
}

\begin{abstract}
This paper is an outcome of a survey that sought to analyse the use of ICT in idea development in the design process with respect to graphic design education in the second cycle institution. The focus was to examine the effect of the introduction of ICT into the curriculum of graphic design education in the Senior High Schools (SHS) on idea development. Quantitatively, data was gathered from two hundred and twenty students from four different SHS in Kumasi, where graphic design is pursued as an elective course in visual art. There was evidence to suggest that even though ICT as a tool is studied in schools, design students were not officially allowed to either assess the internet or use the computer for idea development. However, there were evidence to suggest that students mostly assess the internet and use the computer for their assignments in their respective homes. The results also affirmed that ICT helped in their idea development even though per the pedagogy, teachers do not teach the students. The study however recommends that curriculum developers take another look at the curriculum in shaping the thoughts of these students since the early and proper use of ICT by design students will help in the thinking on the use of technology in the higher education institutions. Moreover, it will also help in the realization of their full potential of technology in idea development in the design process, especially in developing countries.
\end{abstract}

Keywords: idea development, pedagogy, computer technology, ICT

DOI: $10.7176 / \mathrm{ADS} / 90-04$

Publication date: February $28^{\text {th }} 2021$

\section{Introduction}

In recent times the advancement of technology has given rise to the use of ICT in various programmes in education. In the area of design education in the higher education, technology is affecting the ideation process in graphic design (Appiah \& Cronjé, 2012). In the senior high school system in Ghana, ways of doing things manually have also changed dynamically, with the introduction of computer technology. This study is situated in Ghana, a West African country where computers have recently been introduced as educational tools in the Senior High School (SHS) system, with reference to graphic design programme. The introduction was to help the SHS students, develop computer skills in accessing information, and developing ideas, especially in graphic communication media. Studies have shown that the introduction of computer as a graphic design tool in the teaching and learning of graphic de sign has been a source of worry for educators in the pedagogy of design education (Appiah \& Cronje, 2014), especially in the HEI. In the HEI, students are now using ICT to circumvent the design process as far as ideation is concerned (Appiah \& Cronjé, 2012). Anecdotal evidence suggests that students in the SHSs also resort to computer technology even though the pedagogy does not support that. The 'silence' and 'secret' use of computer technology should also be a concern for design educators, especially when these students end up in the HEI. That notwithstanding, researchers believe that when it comes to graphic design education, idea development that is a key issue that facilitates creativity has to be traditionally manual. The following objective was therefore set for this study:

- To assess the extent to which the introduction and the use of ICT influence idea development in Graphic Design by students in the senior high schools (SHSs); an viz-a-viz students attitude on idea development with the introduction of ICT in their graphic design programme.

\section{Literature Survey}

Yeoh (2002) in an earlier study, supported the use of computer technology in Graphic design since the profession has become dynamic; where strategies and products communicate and continually evolve due to the market it serves, the people it targets, and the medium it uses. Computer technology in Graphic Design has therefore become such an important and an imperative item for designers. Yeoh (2002) affirmed in his study that in graphic design, computer technology has become an ideation and production tool. To be competent in the use of ICT for the many tasks that need to be accomplished in the profession is very key.

Yeoh's study revealed that, students have shifted from the traditional way of conceiving and creating ideas 
to the use of technology for idea generation processes. Appiah and Cronjé (2013) also asserted that, the teaching and learning of graphic design has also been affected by the technological modifications, resulting in the introduction of ICT, especially in the developing economies. They also affirm that the introduction of technology into graphic design education introduces a unique problem in relation to the pedagogy of ideation and call for a review of pedagogy for design education in the area of ideation. Yeoh (2002) earlier in his study, observed that the syllabus for design in the study he conducted was structured to include practical base activity, which is executed effectively with the use of technology, from the idea development to the final execution of a design solution. With the design profession having been expanded to include technology - and currently used to portray a profession of wide based of actions - students therefore might require the training of the use of technology at an early stage.

Literature supports the view that graphic design consists of complex decision making in idea development which helps solve design problems (Dorst \& Cross, 2001; Dorst, 2006). If design is to be seen as an activity or process that explores the best way of communicating idea, product or image, then the use of ICT must be imperative in its execution.

A survey by Ametordzi, Osei-Poku \& Eshun (2012) revealed that Art is essential, especially when it functions as a tool to communicate ideas to people. The significance of Art and design contributions into the society and the global world led the educational policy makers in Ghana to introduce Visual Art at all levels. It included the introduction of Basic Design and Technology (BDT) in the Junior High Schools and, visual art programme in the second cycle school in 1991. The programme aimed among other things, to give the young ones (Pupils and students) a strong foundation in creativity and to help develop in them, the spirit of innovation, resourcefulness and creativity (Curriculum Research Development Division, 2008). In reference to the SHS Graphic Design Syllabus, Graphic design is a facet of the Visual Arts curriculum sought after in Senior High Schools throughout Ghana. The introduction of ICT in the graphic design syllabus at this level focuses on developing computer skills in assessing information, ideas and designing graphic communication media (Curriculum Research Development Division, 2008). This assertion is enforced in third year of the section six of graphic design plan syllabus (Figure 1) where the computer is seen as a visual communication instrument.

\section{SENIOR HIGH SCHOOL - YEAR 3}

\begin{tabular}{|c|c|c|c|c|}
\hline & & $\begin{array}{c}\text { SECTION SIX } \\
\text { COMPUTER AS A GRAPHIC DESIGN } \\
\text { General Objectives: The student wil }\end{array}$ & TOOL & \\
\hline UNIT & SPECIFIC OBJECTIVES & CONTENT & $\begin{array}{l}\text { TEACHING AND LEARNING } \\
\text { ACTIVITIES }\end{array}$ & EVALUATION \\
\hline $\begin{array}{l}\text { UNIT } 1 \\
\text { INTRODUCTION } \\
\text { TO COREL DRAW } \\
\text { AND ANY OTHER } \\
\text { SOFTWARE } \\
\text { - Paint box, } \\
\text { Photoshop } \\
\text { Illustrator } \\
\text { Quak-xpres. } \\
\text { etc }\end{array}$ & $\begin{array}{l}\text { The student will be able to: } \\
\text { 6.1.1 use the computer to } \\
\text { design visual } \\
\text { communication media } \\
\text { items. }\end{array}$ & $\begin{array}{l}\text { Computer aided work. } \\
\text { Note:- loons are small pictures or symbols } \\
\text { on a computer screen that you point to } \\
\text { and dick on with a mouse to give the } \\
\text { computer an instruction. } \\
\text { i) creating images with the computer } \\
\text { ii) designing visual communication } \\
\text { items } \\
\text { iii) acoessing and presenting information }\end{array}$ & $\begin{array}{l}\text { Guide students to identify various icons } \\
\text { of the sottware } \\
\text { Assists students to create images using } \\
\text { the icons of the sottuare } \\
\text { Students to use the computer to design } \\
\text { greetings cards, posters, etc. } \\
\text { Students display their works and } \\
\text { discuss. } \\
\text { NoTE: } \\
\text { The computer with its accessories and } \\
\text { other ICT gadgets can be used as tools } \\
\text { to enhance the teaching and learning of } \\
\text { graphic design and pertorming tasks in } \\
\text { eg. drawing. designing. painting. layout } \\
\text { designing, composure, lustration, } \\
\text { cartooning, animation, etc. }\end{array}$ & $\begin{array}{l}\text { Students to: } \\
\text { - use computer to design } \\
\text { and produce an item to } \\
\text { satisty an identfied need } \\
\text { eg. book cover, book } \\
\text { jacket, poster, sticker. } \\
\text { greeting cards, package } \\
\text { design and labels, } \\
\text { business card, trade } \\
\text { mark, logo, etc. }\end{array}$ \\
\hline
\end{tabular}

Figure 1: Teaching Syllabus

Graphic design and idea development involve evolutionary and dynamic processes of creating something new. Ideation therefore is to be understood as an activity to conceive a plan for a particular function or effect (Yeoh, 2002). Design practitioners and educators believe and agree, that all design solutions are supposed to emerge from the process of idea development, which is evident in the solution presented in a specific given task, either for academic or professional. Every idea conceived has its own process before it reaches its final stage of finish, based on the underlying decision making of the designer and should satisfy the design brief of the said project, so that the final product will be appreciated by the client/stakeholders. The survey of Dunmill and Arslanagic (2006) also reveal that ICT involves a range of human-devised hardware, software and telecommunication technologies that ease communication and sharing of data across boundaries, which may be utilised to generate art experience and aims. Information and communication technologies (ICT) have become indispensable tools in today's information age, making a dramatic impact on the lives of people globally. This 
effect is most significant in education. Research has revealed that ICT has also improved learning outcomes (Yeoh, 2002; Arntson, 2011; Appiah \& Cronje, 2014). It has also been proved by researches on the benefits that is achieved by students, instructors and administration with the use if ICT in graphic design and communication of basic idea in development. In recent years graphic design has made a positive impact on the economic development of the nation and has improved the quality of life in most parts of the world.

Generating and transforming representation in design ideation also agrees that ideation has traditionally looked at the most creative and abstract view of the design process because it is inherently connected to the imaginary. ICT as a tool for idea development has also developed a new approach for designers in talking the ramifications that have arisen as a result of technology especially in the process of idea development (Appiah \& Cronje 2014). It is from these simple operations that students are able to fully move into the use of computers as a graphic design tool, which would require some advance level of operation to be successful in its usage. It was also discovered that it is the responsibility of the teacher to teach the students to understand the use of these tools, as well as how far they can practice with the tools as well.

While these issues are pertaining to the HEI, there is the need to look at how idea development is also being handled in the senior high schools. This is because these senior high schools serve as the bedrock of university education and the possibility of wrong foundations being created, can be a great factor to what pertains in the HEI. The study therefore was to engage in the objective to assess the use of ICT for idea development in Graphic Design, with reference to the Senior High School, as a way of looking at how ICT is informing the activities of ideation in the senior high schools.

\section{Methodology}

Based on the researchers' philosophical assumptions from the positivist point of view, the study adopted a quantitative inquiry as a way of bringing to light, how ICT impacts upon idea development in the Graphic Design curriculum and programme. It allowed for specific, narrow questions; collected quantifiable data from participants and analysed these numbers using descriptive statistics inquiry in an unbiased, objective manner (Bauer \& Brazer 2011).

This was appropriate since it helped describe how ICT is used and perceived, and its impacts on idea development in Graphic Design education; either positively or negatively. This also allowed an assessment of the use of ICT in Graphic Design with respect to idea development; and to also examine students' perceptions about idea development following the introduction of ICT into their Graphic Design programme.

The population under study were students from four public SHS in Kumasi offering Graphic Design. These schools are namely Armed Forces Senior High school, TI Ahmadiyya SHS, Mankranso SHS and Barekese SHS. While Armed Forces senior high school and TI Ahmadiyya SHS are located in the Kumasi metropolitan assembly, Mankranso SHS and Barekese SHS are located in different districts in the Ashanti Region. These schools were purposely chosen since they were part of the sampled schools selected for the implementation of the SHS Graphic Design syllabus that encourages ICT in visual art. The introduction also resulted in the introduction of computers to the schools. This was to allow students to have a practical feel of the computer and ICT. Hitherto, ICT was theoretically taught; without the practical lessons due to inaccessibility to computer labs. Hence, the choice of these two schools, Armed Forces Senior High School and TI Ahmadiyya SHS against Mankranso SHS and Barekese SHS was based on their ICT infrastructure. ICT infrastructure here implies accessibility to the internet and mobile phone networks, plus student access to a mobile phone. With a questionnaire, made up of nineteen (19) closed-ended questions, the study sought to gather information about students' usage of ICT, their cognitive process, and understanding of the design process, technical skills, attitudes and perception towards idea development with ICT as a tool. These perceptions were based on the content of the graphic design syllabus provided by the educational service and ICT's role in graphic design, how it is being used and its impact as well. The purposive sampling technique adopted was based on the indication that the current third year students had gone through ICT and ideation since the first year of their study. The data gathered were analysed quantitatively using the SPSS.

\section{Discussions and Results}

The first objective of the study was to analyse the use of ICT for idea development in graphic design process by students in some selected senior high schools. Dataset from the study indicated that, even though technology has been introduced in the study of graphic design at the senior high school level, the schools still rely heavily on the use of the traditional tools for idea development (Table 1).

Table 1: Tools used for Idea Development

\begin{tabular}{lll}
\hline TOOLS & FREQUENCY & PERCENTAGE \\
Pencil/Pen & 174 & 82.1 \\
Computer & 33 & 15.6 \\
\hline
\end{tabular}

Students indicated their reliance on the use of traditional tools of pencil/pen on paper as the main tool for 
idea development. This result from the data runs alongside a study by Tan, Melles \& Lee (2009). In their study on technology with ideation, it revealed practicing graphic designers confronted with broad and ill-defined design challenges, sought to rely heavily on the traditional tools to sketch and draw for early ideas. This results also support the idea that, when it comes to idea development, designers cannot do without thumbnail sketches as they help in promoting creative works (Tan, Melles \& Lee, 2009). A situation that also runs contrary to Yeoh's (2002) study. Significantly, results from the study suggested that the use of ICT in idea development by the students is done against the pedagogy captured by the syllabus. The teachers seem not to be aware of the fact that students are using the software outside the school.

\section{ICT for idea development in graphic design process by SHS students}

From the data gathered, the study can deduce with the following analysis

- Students greatly rely on the use of pencil/pen on paper as the main tool for idea development in the senior high schools, but with some technology support.

- Though the use of traditional tools is of the majority preference, there was significant knowledge of design software (as captured in the syllabus) by the students. Significantly these softwares were never taught in their schools, as the syllabus seems to suggest.

- That students know how to use the software and are applying them in their assignments, on the blind side of their teachers was worrying and educators will have to do something quickly in respect of the pedagogy.

- That majority of respondents (86.78\%) use ICT (technology) most of the time for their initial research activities for idea development. Such usage of technology assessment for preliminary studies in their idea development could as well enhance the knowledge of the students and lead to high-quality presentation of design solutions (CRDD Teaching Syllabus for Graphic Design, 2008).

- Though respondents indicated they use traditional tool mostly for their work, the findings indicated that technology was prominent especially when it comes to their initial search for ideas with sketches. A study by Stones and Cassidy (2007) points out that sketching as a tool is not always used in isolation - a sketch may be consulted whilst on the computer screen since a word may trigger an idea rendered in sketch form.

- Only a quarter of the respondent (25.8\%) accessed internet from the schools (Table 2), even though the schools are provided with computers and internet facilities. The rest access internet at home with ease and at the cafés; especially when most assignments are executed outside the schools. This technology usage becomes prominent when it comes to their initial search for thumbnail sketches for solutions to their design assignments.

Table 2: Accessing the computer and internet for preliminary studies

\begin{tabular}{|c|c|c|c|c|}
\hline \multirow[t]{2}{*}{ Tool } & Place of Usage & $\begin{array}{l}\text { No. of } \\
\text { Response }\end{array}$ & $\begin{array}{l}\text { Percentage of } \\
\text { Response }\end{array}$ & $\begin{array}{l}\text { Missing } \\
\text { Responses }\end{array}$ \\
\hline & Home & 91 & 42.9 & 121 \\
\hline \multirow[t]{2}{*}{ Internet } & School & 55 & 25.9 & 157 \\
\hline & Internet Café & 64 & 30.2 & 148 \\
\hline
\end{tabular}

Against the background that students use ICT in their initial research for idea development, the study went further to know how and where respondents access internet for their preliminary studies. These findings confirm the knowledge that access to computers in the schools is still below the acceptable standards in terms of numbers being demanded (Ministry of Education, 2015). It was also significant to note that, while teachers are not allowing students to access the computer in schools - due to lack of the required number of computers on campus - students find ways of learning and using the computer technology without any pedagogical directions. It is believed that the usage of the computer technology will increase on campus if all schools were to be equipped for ICT implementation.

This study also looked at whether students, in their initial preparations of idea development, were resorting to the use of ICT (as per the aims of the curriculum of the study; CRDD, 2008). According to the curriculum, usage of technology for preliminary studies in idea development could enhance the knowledge of the students and lead to high-quality presentation of their works (Curriculum Research Development Division, 2008). Appiah and Cronje (2014) posit that the introduction of ICT; specifically, computer technology, has helped to develop a new approach for designers in tackling the ramifications that have arisen from the use of technology, especially in the process of idea development. The concept of developing thumbnail sketches using a computer software is mostly affected by environmental factors (Bandura, 1991). While ICT account for initial research activities for idea development, there were series of documents from the works exhibited by student of positive impact with the use of ICT in the idea development of the students' artworks in Graphic Design. Indeed, results from the dataset indicated positive results on the adoption and use of ICT for final works 
Even though it might not be a big deal for students to have access to the computer facilities in their home, it still adds up to their skill development. However, there could be more positive impact within the school due to the learning atmosphere involved. It is, however, expected that the school should create an atmosphere of motivation where such topics and activities under the preliminary studies in the graphic design programmes are undertaken. For pedagogical reasons, majority of the respondents had access to the computer in their homes. These findings confirm the fact that access however is still below the standards and numbers demanded (Ministry of Education, 2015).

\section{Conclusion}

Issues related to the students' thought-processes (cognition) show that students strongly agree that the introduction of computer in graphic design has made idea development easy for them. With regard to issues related to the design process, the study indicated a positive response of skills acquired in the design process and this has increased students' application of software to design activities. This activity recorded the highest mean value with students also in agreement with the fact that they are able to generate their own ideas using the internet.

What is worth noting is that the purpose of graphic design education is to prepare students for professional practices (Resnik, 2003). It was realised that students were using relevant software application to create alternative ideas as far as design process of graphic design is concerned. If it is required to use ICT in idea development in graphic design, then the pedagogy should be clear for both students and the teachers. There is the possibility of serious distortion at this stage in their earlier years of study. At this stage, there is also the possibility of students getting set for the job market as professionals. Being able to generate ideas in a number of different ways, appropriately to the needs of graphic design professionals should be something educators can take another look at. To meet the challenges of deadlines, budgets, productions and logical concerns and client, imposed restrictions, each project work requires its own method of approaches to the solution. Students will strongly want to adopt such approach in executing their assignment. However, pedagogical models need to be realized to meet today's need in graphic design education in emerging countries. Notwithstanding, the use of traditional means of developing ideas and designing, graphic design in the SHS has been minimal but not wholly abandoned in terms of the use of ICT software for final design solutions. We recommend that policies regarding graphic designing should be implemented by educational authorities so that the demand put on the subjects could be met at the level regarding the use of computers as a graphic design tool.

\section{References}

Ametordzi, S. Osei-Poku, P. \& Eshun, E. F. (2012). Pedagogical Situations and Learning Outcomes in Graphic Design in Selected Senior High Schools in the Kumasi Metropolis of Ghana. International Journal of Innovative Research and Development. 1 (19), 178-91.

Appiah, E. \& Cronjé, J. C. (2012). Thumbnail Sketches on Idea Development: The Drawing Board vs Computer Generation. Art, Design \& Communication in Higher Education. 11 (1), 49-61.

Appiah, E. \& Cronjé, J. C. (2013). Information Communication and Technology (ICT) and the Challenges of Ideation in Graphic Design: An Activity Theory Focus. International Journal of Computer Applications. 63 (6), 13-23

Appiah, E. \& Cronjé, J. C. (2014). The Influence of Information and Communication Technology on Graphic Design: Reflections on Pedagogy. Journal of Science and Technology. 34 (1), 85-94.

Arntson, A. E. (2011). Graphic Design Basics. Australia, Cengage Learning.

Bandura, A. (1991). Social Cognitive Theory of Self-Regulation. Organizational Behavior and Human Decision Processes. 50 (2), 248-287.

Bauer, S. C. \& Brazer. S. D. (2011). Using Research to Lead School Improvement: Turning Evidence into Action. Thousand Oaks, Calif, SAGE

Curriculum Research Development Division (2008). Graphic Design. Accra, Ministry of Education Youth and Sports.

Dorst, K. \& Cross, N. (2001). Creativity in the Design Process: Co-Evolution of Problem - Solution. Design Studies 5 (5): 425-37.

Dorst, K. (2006). Design Problems and Design Paradoxes. Design Issues 22 (3): 4-17.

Dunmill, M. Arslanagic, A. (2006). ICT in Arts Education - A Literature Review. New Zealand Ministry of Education.

Ministry of Education (2015). ICT in Education Policy. Ghana, Ministry of Education.

Resnik, D. B. (2003). Design for Communication: Conceptual Graphic Design Basics. New Jersey, Willey.

Stones, C. \& Cassidy, T. (2007). Comparing Synthesis Strategies of Novice Graphic Designers Using Digital and Traditional Methods. Design Studies 28 (1), 59-72.

Tan, S., Melles, G. \& Lee, N. (2009). Graphic Designers' Activities during the Conceptual Design Phase of 
Client-Initiated Projects. Art, Design \& Communication in Higher Education 8 (1), 85-92.

Yeoh, K. C. (2002). A Study on the Influences of Computer Usage on Idea Formation in Graphic Design Students. Texas Tech University.

Ametordzi, S. Osei-Poku, P. \& Eshun, E. F. (2012). Pedagogical Situations and Learning Outcomes in Graphic Design in Selected Senior High Schools in the Kumasi Metropolis of Ghana. International Journal of Innovative Research and Development. 1 (19), 178-91.

Appiah, E. \& Cronjé, J. C. (2012). Thumbnail Sketches on Idea Development: The Drawing Board vs Computer Generation. Art, Design \& Communication in Higher Education. 11 (1), 49-61.

Appiah, E. \& Cronjé, J. C. (2013). Information Communication and Technology (ICT) and the Challenges of Ideation in Graphic Design: An Activity Theory Focus. International Journal of Computer Applications. 63 (6), 13-23

Appiah, E. \& Cronjé, J. C. (2014). The Influence of Information and Communication Technology on Graphic Design: Reflections on Pedagogy. Journal of Science and Technology. 34 (1), 85-94.

Arntson, A. E. (2011). Graphic Design Basics. Australia, Cengage Learning.

Bandura, A. (1991). Social Cognitive Theory of Self-Regulation. Organizational Behavior and Human Decision Processes. 50 (2), 248-287.

Bauer, S. C. \& Brazer. S. D. (2011). Using Research to Lead School Improvement: Turning Evidence into Action. Thousand Oaks, Calif, SAGE.

Curriculum Research Development Division (2008). Graphic Design. Accra, Ministry of Education Youth and Sports.

Dorst, K. \& Cross, N. (2001). Creativity in the Design Process: Co-Evolution of Problem - Solution. Design Studies 5 (5): 425-37.

Dorst, K. (2006). Design Problems and Design Paradoxes. Design Issues 22 (3): 4-17.

Dunmill, M. Arslanagic, A. (2006). ICT in Arts Education - A Literature Review. New Zealand Ministry of Education.

Ministry of Education (2015). ICT in Education Policy. Ghana, Ministry of Education.

Resnik, D. B. (2003) Design for Communication: Conceptual Graphic Design Basics. New Jersey, Willey.

Stones, C. \& Cassidy, T. (2007). Comparing Synthesis Strategies of Novice Graphic Designers Using Digital and Traditional Methods. Design Studies 28 (1), 59-72.

Tan, S., Melles, G. \& Lee, N. (2009). Graphic Designers' Activities during the Conceptual Design Phase of Client-Initiated Projects. Art, Design \& Communication in Higher Education 8 (1), 85-92.

Yeoh, K. C. (2002) A Study on the Influences of Computer Usage on Idea Formation in Graphic Design Students. Texas Tech University. 